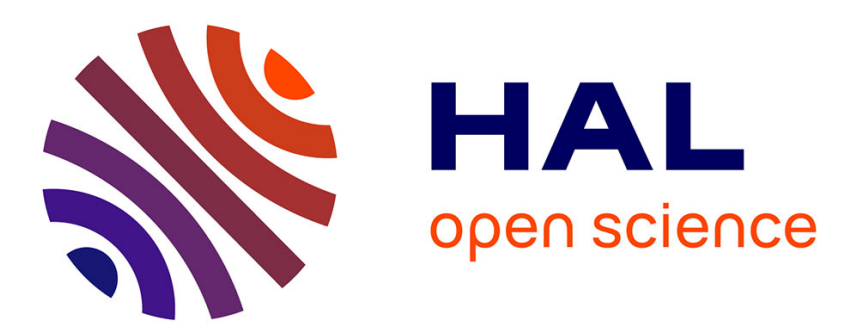

\title{
Europe in global maritime flows: Gateways, forelands, and subnetworks
}

César Ducruet, Olivier Joly, Marine Le Cam

\section{To cite this version:}

César Ducruet, Olivier Joly, Marine Le Cam. Europe in global maritime flows: Gateways, forelands, and subnetworks. Kathy Pain; Gilles Van Hamme. Changing urban and regional relations in a globalizing world. Europe as a global macro-region, Edward Elgar, pp.164-180, 2014. halshs-01069174

\section{HAL Id: halshs-01069174 \\ https://shs.hal.science/halshs-01069174}

Submitted on 28 Sep 2014

HAL is a multi-disciplinary open access archive for the deposit and dissemination of scientific research documents, whether they are published or not. The documents may come from teaching and research institutions in France or abroad, or from public or private research centers.
L'archive ouverte pluridisciplinaire HAL, est destinée au dépôt et à la diffusion de documents scientifiques de niveau recherche, publiés ou non, émanant des établissements d'enseignement et de recherche français ou étrangers, des laboratoires publics ou privés. 


\section{Europe in global maritime flows: Gateways, forelands, and subnetworks}

\section{DUCRUET César}

French National Centre for Scientific Research (CNRS)

UMR 8504 Géographie-Cités

13 rue du Four, F-75006 Paris (France)

Tel. +33(0)140464000; Email: cdu@ parisgeo.cnrs.fr

JOLY Olivier

Interdisciplinary Research Centre on Mobilities (CIRTAI)

University of Le Havre \& UMR 6266 IDEES

25 rue Philippe Lebon, F-76086 Le Havre (France)

Email: olivier.joly@univ-lehavre.fr

LE CAM Marine

French National Centre for Scientific Research (CNRS)

UMR 6266 IDEES

Pre-final version of the chapter published in K. Pain \& G. Van Hamme (eds.), Changing Urban and Regional Relations in a Globalizing World. Europe as a Global Macro-Region, Edward Elgar, pp. 164-180.

\section{Introduction}

Whilst processes of globalization raise new challenges for research to quantify and map the geographies of spaces of invisible financial and trade flows, increasing virtual connectivity between places has in fact been accompanied by an intensification of physical movement, of people and goods, endorsing the ongoing importance of location and distance (Hall and Hesse, 2012). This point is illustrated by the fact that in the new millennium, ninety per cent of both global trade and Europe's external trade volumes are transported by sea. Ports and maritime transport are thus key elements of globalization processes (Shaw and Sidaway, 2010), making it crucial for our research to examine the position of Europe's port gateways in global shipping flows. 
As argued by Lewis and Wigen (1999), depictions of the metageography of the world have traditionally been dependent on a continental, land-based analytical perspective. Hence important questions have for too long been overlooked in spatial analysis. How do the specific patterns of maritime flows compare with those of other important global flows such as finance or air transport? How do they influence wider territorial dynamics within and outside Europe? The main purpose of this chapter is thus to verify how patterns of inter-port links can contribute to our understanding of the potential emergence of a European macro-region, and to our understanding of the position of Europe as a whole in global sea traffic.

The position of Europe in maritime flows is demonstrated by the connections of its port gateways with the rest of the world. Such connections vary from one port to another in terms of traffic concentration and geographic coverage, dependent on multiple factors including origin-destination time and cost factors, shipper and ocean carrier decisions, and the size, quality, and specialization of local port infrastructures. A key research challenge is therefore to unravel the relationships between internal and external dynamics; in other words, how do the emergence and position of European maritime flows interplay with the distribution of its port system and how have such patterns been influenced by the evolution of other regions, such as Asia, where port dynamics are profound and rapid.

Analysis of the geographic coverage and hierarchy of maritime flows is reliant upon the two major concepts and research fields in transport geography: port systems, and maritime forelands. Research on port systems, or systems of ports, often look at changing traffic concentration levels among neighbouring ports (see a review by Ducruet et al., 2009). On the other hand, studies of maritime forelands focus more on the overseas connections of ports and their evolution, classically conceptualized as the maritime side of port dynamics and complementary to the port itself and its hinterland (Weigend, 1952; Robinson, 1970; Vigarié, 1979). There has been a recent revival of interest in the study of forelands, which were the focus of early port geography research (see $\mathrm{Ng}$ and Ducruet, 2012), with notable recent case studies of ports in North Korea (Ducruet, 2008), Maghreb (MohamedChérif and Ducruet, 2011), China (Wang and Ng, 2011), and France (Guerrero, 2012). More global approaches to the analysis of port systems and maritime forelands have yet to emerge due to longstanding difficulties in accessing relevant information on shipping flow s (Ullmann, 1949; Marti and Krausse, 1983), notwithstanding some recent research contributions adopting a network approach to analysis, putting the overall structure of the network at centre stage (Joly, 1999; Kaluza et al., 2010; Ducruet and Notteboom, 2012). A further limitation to global maritime research is that studies are often embedded within broader research projects primarily concerned with urban and multimodal accessibility (European Union, 2010) and focusing on specific dimensions such as individual ocean carrier strategies and geographic coverage (Frémont, 2007), port and maritime network vulnerability 
in relation to their dependence upon transoceanic canals (Ducruet, 2012), or specific historic time periods ${ }^{1}$.

This chapter tackles these lacunae by analyzing the global pattern of maritime flows using previously untapped data on merchant vessel movements in 2004 and 2011. This period has specific relevance because it allows investigation of the impacts of the 2008 global financial crisis which had deep repercussions for maritime traffic, amongst other dynamics (De Monie et al., 2011). Since recent research has mostly focused on container flows, the present analysis also includes raw materials flows (i.e. bulks) because different commodities may have different spatial patterns as containers, the most valued shipments, are carried through regular (liner) services and bulks are transported via nonregular, on-demand (also called tramping) services.

The chapter is organized as follows: First we explain in more detail, the methodological issues and choices which have confronted and structured our analytical approach. Second, we present out findings by mapping and interpreting Europe's position, influence and coherence in global maritime flows using cartographical and network analytical tools. Third we complement these results by classifying the maritime forelands of European ports based on the specialization of their geographic coverage. Finally, we present our conclusions about the importance of ports for European development and for the world economy as a whole.

\section{Data and methodology}

Our data were obtained from the Lloyd's List, the world's main maritime insurance company, covering about $80 \%$ of the world fleet. The list provides information on the daily movements of merchant vessels, including the sequence of port calls, and information about vessels' carrying capacity, type of commodity, etc. Due to the volume and cost of this information, our analysis has been restricted to specific key months of circulation: October 2004 and May 2011. Due to the absence of information on vessel types and capacities in 2004 in the paper version of Lloyd's Voyage Records (LVR), missing data were retrieved from additional vessel databases such as Fairplay World Shipping Encyclopedia ${ }^{2}$, MIRAMAR Ship Index ${ }^{3}$, DNV Exchange ${ }^{4}$, and the World Shipping Register ${ }^{5}$. This required considerable efforts due to the absence of IMO (International Maritime Organization) numbers of vessels. Since many vessels regularly change their names and flags, the risk of confounding them

\footnotetext{
${ }^{1}$ See the CLIWOC project homepage with maps of vessel circulations during the 1750-1854 period: http://www.knmi.nl/cliwoc/

${ }^{2}$ http://www.ihs.com/products/maritime-information/ships/world-shipping-encyclopedia.aspx

${ }^{3} \mathrm{http}: / /$ www.miramarshipindex.org.nz

${ }_{5}^{4} \mathrm{http}: / /$ exchange.dnv.com/exchange/Main.aspx

${ }^{5}$ http://e-ships.net/
} 
across databases was avoided by taking into account their type, subtype, year of build, and former names.

Another methodological issue was the choice of tonnage capacity. Although deadweight tonnage (DWT) provides a more accurate picture of a vessel's commercial capacity (excluding reservoirs, decks, rooms, etc.), the Gross Registered Tonnage (GRT), which corresponds to the volume of the entire vessel, was selected for analysis due to its wider availability in ship registers. Measuring the weight of maritime flows based on GRT figures, however, may undermine the importance of some commodities as there is no proportionality between DWT and GRT. In any case, the occupancy ratio of vessels (i.e. the number of tons actually carried on each trip) as well as the volume of freight handled at each port, is not specified by the data sources. Thus, it was assumed that the overall capacity (GRT) of vessels is a good indicator of the importance of flows. Vessel capacities were summed by port and by interport link during each period of movement. This results in the elaboration of an origin-destination (OD) matrix to be considered as a weighted, undirected graph as in other studies of accessibility in networks (Rodrigue et al., 2009). Traffic flows are thus calculated by taking into account the volume and the frequency of vessel trips between locations.

Lastly, vessel types were aggregated in different categories, such as liquid bulk (i.e. asphalt, crude oil, oil products, chemicals, liquefied natural gas, liquefied petroleum gas, water, wine, edible oil, and unspecified tankers), solid bulk (i.e. aggregates, cement, ores, and unspecified bulks), and containers. General cargo vessels were excluded due to the high cost of purchasing their movements in digital format for $2011^{6}$, as it is the most numerous fleet. Flows of roll-on/roll-off (ro-ro) vessels, which typically carry trucks and vehicles, are not analyzed separately since they are often restricted to shortsea shipping services and remain mostly intra-regional.

\section{Macroscopic patterns}

Three geographical levels are considered: continents, maritime ranges, and ports. Here and in the following section on nodal regions we make use of single linkage analysis methods to simplify the pattern of flows and identify key structures. For each node in the network (i.e. continent, region, and/or port), we keep only the largest flow link with another node, which is believed to extract hidden patterns such as node hierarchies and the geographic coverage of their tributary areas. In the case of continents and maritime ranges, the second largest link has been considered in order to avoid losing too much information, as in the multiple linkage analysis method (Puebla, 1987).

\footnotetext{
${ }^{6}$ Since 2009 onwards, Lloyd's List does not publish paper versions of its registers.
} 
At the level of continents (figure 1), the first results underline a rapid and paramount increase of AsiaPacific in global shipping, from 36.9 per cent in 2004 to 49.1 per cent in 2011 of world total traffic. Europe has witnessed the highest drop in traffic shares from 24.4 to 20.8 per cent, followed by West Asia, North America, Africa, and Latin America. The overall pattern of flows has remained rather stable, with a polarization upon Asia-Pacific and Europe, the latter being a subordinate of the first because Europe's largest link connects Asia. While Latin America and Africa have their largest traffic links with Europe, North America, West Asia and Europe itself are dominantly connected with AsiaPacific for both years. The relative importance of Europe in other regions' traffic has also remained stable, except for a noticeable drop in Latin America. The share of Europe has actually declined for all regions except Africa $(+2.2 \%)$, the largest drops being Latin America (-5.1\%) and Asia-Pacific ($3.4 \%)$. Conversely, intra-European flows have increased their share of total traffic from 36.3 per cent to 40.8 per cent. Such dynamics underline the shrinkage of Europe's global position and the reinforced polarization of world flows by Asia-Pacific.

[Insert Figure 1 about here]

Regarding the level of maritime ranges (figure 2) that correspond to the definition of regions given by Lloyd's List, a number of disconnected components emerge and reveal macro-regional patterns. A large Asia-Pacific pole centered upon China and Korea, ranges from the U.S. West Coast to the Red Sea and East Africa. North and South Europe remain separate entities for both years. In 2004, the North American East Coast is included in a vast Atlantic pole comprising the rest of the Americas, Northwest Africa, and Europe; in 2011, it is included in another pole comprising the U.S. Gulf, Central America, and Southwest America. All of these poles strongly connect neighbouring regions. Many changes are highlighted, such as the stronger polarization of global shipping flows by the ChinaKorea region and the weakening of trans-Atlantic links, as already observed by Ducruet and Notteboom (2012) in the case of container flows between 1996 and 2006. The link between Southeast Asia and China-Korea remained the heaviest between 2004 and 2011. Such patterns may have been influenced by the combined effects of the 2008-2009 global financial crisis (i.e. the lowering of longdistance trades) and of pursued intra-regional trade cooperation in Asia and other regions such as Europe and the Americas. The reinforced internal connectivity of Europe as well as its decreasing global importance is highlighted for numerous maritime ranges. Outside Europe itself, only Northeast America, Northwest Africa, and the Red Sea maintain significant shares of Europe-related traffic in their total traffic. The highest drops occurred in Southwest America (-6.5\%), Southeast America (5.4\%), Central America and Caribbean (-4.5\%), and Southeast Africa (-4.1\%). Such trends directly illustrate macro changes in trade patterns such as the shift of African traffics towards Asia 
(Chaponnière, 2010) and the extension of Asia's influence towards Latin America, notably in the case of solid bulks.

[Insert Figure 2 about here]

At the port level (figure 3), specialization in European traffic appears more evident. North and West African ports have a very significant share of their traffic polarized by European ports. This directly reflects Maghreb's specialization in bulk exports (e.g. liquefied gas and oil products, minerals) to Europe as well as its historical ties with France. Alexandria and Damietta (Egypt), Casablanca and Tangier (Morocco), as well as many Libyan, Algerian and Tunisian ports have the largest volume and share of Europe-related traffic. Outside of this Euro-Africa area, only Montreal (Canada) combines both high volume and high share; all other ports specialized in European traffics remain rather small, such as in the Antilles (e.g. Pointe a Pitre, Fort de France), South America's East Coast (e.g. Cayenne, Santarem, Natal), and the Indian Ocean (e.g. Mauritius). The rest of the world remains far less specialized in European traffic, especially the Asia-Pacific area. As a confirmation of previous results, the overall pattern did not change much in 2011, although the decline of European traffic is significant outside specialized ports. Europe's tributary area for trade shrunk spatially, whereas other poles extended their influence, notably across the Southern hemisphere.

[Insert Figure 3 about here]

\section{Port hierarchies and nodal regions}

A very useful method to capture both the hierarchical and geographical effects of flow patterns is the application of single linkage analysis to world shipping flows at port level (figure 4). Bisecting the world graph into subgroups, each with its own dominant port, allows for mapping distinct nodal maritime regions. They are interpreted here as basins of intense interaction, and their geographic dimension can be tested through cartography. The regionalization of shipping flows can highlight crucial aspects of a port's ability to dominate others as an effect of various factors such as port infrastructure size and quality, shippers and carriers' logistics decisions, etc. (Robinson, 2002). The way in which Europe as a single entity emerges from the flows beside other regional entities may complement studies of world regionalization. 
In support of previous results, the largest emerging component is centered upon Asia (Singapore being the dominant node), followed by a portion of Europe mostly occupying the North with a small transAtlantic extension toward Canada (Montreal). This means that transatlantic ties have not only shrunk in size, but they have also become disconnected subparts compared with the more integrated Asian group, which extends in 2004 across the Pacific and the Mediterranean basins. The split between North and South Europe may be attributed to the exclusion of land-based networks and flows in the analysis, due to the lack of such data on a world level. However, such absence cannot explain the split of the Atlantic, especially the northern part, into small groups. Most groups outside the Asian one are thus reflections of spatial proximity of range effects among neighbouring ports. The fact that Asia as a whole is dominantly a maritime economy can explain such results, as a large proportion of its internal and external trade occurs by sea, and most of its population and activities are located along its coasts (Lee et al., 2008). Important discontinuities thus influence flow patterns, ranging from physical factors (e.g. coastlines, straits) to human factors of trade routes and carrier decisions. Further research should attempt to integrate road and railway networks, for instance, in order to maintain continental continuity among Europe's cities and regions. This would also provide drastically different results for Asia (weaker inland penetration of logistics chains) and North America (transcontinental land bridges). In addition, this would help to improve understanding of the intermodal importance of some European gateways as well as the relative importance of maritime flows for inland (non-port) cities and regions in Europe and other parts of the world. At present, based on these results, Europe is composed of different maritime subsystems, each having their own internal logic, despite the fact that, in reality, they are complementary and interconnected.

In Europe, Rotterdam stands out as the second largest port after Singapore in terms of its number of subordinates (i.e. ports connecting Rotterdam by their largest flow link). Independent ports can be seen as regional hubs exerting polarization within their maritime range. There is a tendency between 2004 and 2011 for most groups to have become smaller, except for the largest European group which extends further along the West African coast. This confirms results of the previous analysis of macroscopic patterns, revealing that Northwest Africa maintained its dependence on European traffics. Valencia replaced Marseilles at the head of a Western Mediterranean group. The geographic coverage and size of the large Asian group centered upon Singapore is mostly explained by the latter's hub functions for both liquid bulk and container flows internally and externally. There are plans to develop a new liquid bulk hub port in Gwangyang, South Korea, to take over part of this role.

[Insert Figure 4 about here] 


\section{Geographic specialization of maritime forelands}

\subsection{Global analysis}

The application of factor analysis to the regional distribution of world ports traffic reveals the dominant specialization of their maritime forelands. A factor analysis was applied to the each matrix in 2004 and 2011 based on the distribution of traffic between each port and each of the seventeen world regions or ranges. This method allows us to extract the main trends from the original dataset and group variables as well as ports. Four main factors comprise about $65 \%$ and $61 \%$ of the total variance in 2004 and 2011, which was considered sufficient to obtain a global snapshot of foreland specializations.

As expected, the first factor (F1) depicts a hierarchical trend for both years in which largest ports tend to connect primarily (and perhaps to locate in) Asian regions, followed by Southeast Africa, Northwest Europe (only in 2004) and the Middle East. This pattern remains nearly unchanged throughout the period. The second factor (F2) reveals a very interesting trend in which ports bordering the Atlantic and connected seas and basins are opposed to ports bordering the Pacific and connected seas and basins. This clear divide between the world's two main oceans confirms previous results and underscores the importance of proximity links and regional dynamics. In the global network of container shipping, for instance, about $80 \%$ of interport links occur along a distance of 500 kilometers or less (Ducruet and Notteboom, 2012), but this can largely be attributed to the way that vessels circulate and connect ports. Unlike air transport, maritime transport connects many intermediate nodes on their voyage from origin to destination, thus greatly exaggerating the importance of local links among adjacent ports. This also stems from the application of hub-and-spokes systems in many regions where one dominant port multiplies connections toward secondary ports.

The third factor (F3) provides another dimension, that is, the opposition between the Americas and the Mediterranean basin (with a slight influence of the Middle East) for both years. This pattern may reveal the importance of North-South trades between North and South America as well as between South Europe and North Africa, where trade exchanges are intense. The fourth factor (F4) somewhat differs in its structure between 2004 and 2011. In 2004, there is an opposition between Northwest America and Southeast Africa, which can be understood when including additional variables as an opposition between two different historical legacies. On the one hand, the grouping of Southeast Africa, West Africa, and Southeast America (and, to a lesser extent, South Asia) with North Europe in general resembles Europe's former colonial world based on North-South linkages. On the other hand, the grouping of Northwest America with Northeast Asia, South Europe, and North Africa (i.e. the Mediterranean basin) constitutes an important segment of the round-the-world trunk line connecting major economic poles. The cartography of the position of individual ports along those four main factors should verify to what extent ports are specialized in regions other than their own, due to the 
importance of long-distance links. Each of the maps (figure 5) represents a cluster of ports defined by the crossing of the aforementioned factors. Overall, they confirm a certain stability of the spatial patterns over time since most trends are logically distributed across space in the form of continuous alignments of ports sharing identical profiles. This is a very satisfactory result given the changes that occurred during the period and the differences in data coverage and collection methods. One main change is the fact that all clusters contain European ports in 2004 whereas in 2011, three main clusters do not. In itself this result again confirms the shrink of European forelands on global and regional scales.

While the specialization on Mediterranean flows involves mostly Mediterranean ports, two other clusters including many European ports expand outside Europe: Europe/West Africa and Europe/South America. . They both illustrate the persistence of former colonial ties through maintained trade and cultural links. This pattern thus reflects the importance of longstanding NorthSouth Atlantic links for Europe. In 2004, the Europe/West Africa cluster includes Rotterdam, Le Havre, Rouen, Southampton, Tees, Felixstowe, Tilbury, Milford Haven, and Gothenburg in northern Europe as well as Lisbon and Algeciras in southern Europe among the largest ports. In 2011, only Felixstowe and Southampton remain from the previous list. The presence of many French ports in this group (also with La Pallice, Donges, Brest, and Le Verdon) confirms the importance of post-colonial linkages. In 2004, the Europe/South America cluster comprises Amsterdam, Antwerp, Bremerhaven, Dunkirk, Hamburg, Immingham, Wilhelmshaven, and Zeebrugge while in 2011, Le Havre and Rotterdam are also included. This confirms the proximity created by specific links of various natures (e.g. Brazil-Germany, Netherlands-West Indies). Yet, the number of non-European ports in this cluster has reduced considerably, the common feature being the Brazilian pole around Santos and Rio de Janeiro. These two major clusters have thus both shrunk spatially and have the peculiarity to include mostly large northern European ports ensuring such long-distance connections. Another example of spatial reorientation is the fourth cluster including Bilbao, Vigo, and Thamesport in 2004 but including only American ports in 2011, partly due to the reinforced North-South integration within the Americas (see Guy, 2003). In fact Bilbao has shifted to the Europe/ West Africa cluster in 2011. All other European ports belong to clusters specialized in Asia-Pacific traffics. They are often much smaller than the European ports of Europe-Atlantic clusters and the trend is their absence in 2011 from the two last clusters of the figure. One interpretation of such patterns is the growing expansion of Asian trades across Europe and the Atlantic, which in turn depreciates Europe's influence by restricting the geographic coverage of its main gateways.

[Insert Figure 5 about here] 
Due to the very high influence of adjacency on the results at the global level, the specific foreland specialization of European ports appears somewhat blurred. For such reasons, only extra-European traffic flows were retained. This resulted in the deletion of 177 ports in 2004 and 159 ports in 2011 due to their absence of extra-European traffics. The choice was made to add three variables on traffic per major commodity group (solid bulk, liquid bulk, and containers) with the assumption that foreland specialization might correlate with commodity specialization.

The results obtained from the application of factor analysis for each year are very significant, as the four main factors captured $83.7 \%$ and $82.7 \%$ of the total variance, respectively. The hierarchical trend observed for F1 is dominated by containers in both years. Although containers have less weight than bulks, their traffic is highly hierarchical due to fierce competition among European ports to develop transshipment and intermodal services (Notteboom, 2010). The best represented forelands on F1 shifted somewhat between 2004 and 2011, from the dominance of Latin America to that of East Asia. This again confirms previous results emphasizing the increased polarization of global maritime flows by Asian ports in general and the parallel retreat of Europe from its traditional forelands. Other factors have similar structures between 2004 and 2011 but with noticeable differences making it difficult to establish direct comparisons.

The second factor (F2) opposes African forelands, liquid bulks and Asian forelands, containers. This is a classical pattern whereby Europe imports containers from Asia and raw materials from Africa, although the analysis does not take into account the directionality of flows. In 2011, the opposition is more between Middle East/Mediterranean/East Asia/Northwest America, containers and South Atlantic/East Africa, solid bulks. This trend seems to echo the 2004 pattern but with a more precise delineation, that is, an opposition between the eastward container trunk line and the North-South raw materials trades (e.g. agricultural products and minerals). The third factor (F3) in 2004, clearly opposes North Africa/Middle East, liquid bulks and Southeast Africa/South America, solid bulks. In 2011, North Africa and the Middle East are grouped with Oceania but without a specific commodity profile, in opposition to the Americas again, without a specific commodity orientation.

The distribution of such trends within Europe itself exhibits a certain spatial order among gateways according to their main orientations. In 2004, Rotterdam, Hamburg and Bremerhaven (together with Tilbury) were the largest ports being specialized in Asian forelands and containers, but also solid bulks and Southeast Africa/Latin America trades. This category is thus very much concentrated in the northern part of the megalopolis as it includes major ports of the so-called Northern Range. The parent category (Asia, containers) having more affinity with liquid bulks and North Africa/Middle East flows is mostly located across the Mediterranean (e.g. Barcelona, La Spezia, Gioia Tauro, Piraeus) and in Southeast England (e.g. Felixstowe). In contrast, numerous large ports are specialized on African trades and liquid bulks (e.g. Le Havre, Algeciras, Marseilles, Genoa), while the largest ports in the last 
category specialize in solid bulks. Latin American and Southeast African trades concentrate mostly along the Atlantic range. Thus, the global distribution of European forelands privileged a few ports having long-distance specializations, while most large ports remained focused on flows with adjacent and traditional partners.

In 2011, some similarities do appear, with Hamburg and several Mediterranean ports having dominant links with Asia and containers. Ports more specialized on East-West container flows are among the largest, except Rotterdam, Marseilles, and Algeciras which are turned more towards North-South flows and solid bulks. These patterns confirm the wider spread of Asian trades across European major gateways and the retreat of traditional Atlantic forelands. Among other factors, the 2008 global crisis might have fostered such dynamics by making European gateways even more specialized in containers and Asia. At the same time, Asian ports have tended to capture those traditional forelands that were once Europe's preferential partners (e.g. Africa and Latin America).

\section{Conclusion}

Using various methods and analyses, we have documented the position and evolution of Europe and its port gateways in global maritime flows based on original data on merchant vessel movements in 2004 and 2011. The main results demonstrate the accuracy of the data due to the fact that results are consistent from year to year and also the enormous potential for vessel movement data to study trade patterns and regionalization processes around the globe.

Overall, our analyses confirm that Europe is no longer a leader in global maritime flows, which are increasingly polarized by Asian ports. The non-inclusion of land-based flows and networks is, of course, partly responsible for such a picture, which is only based on shipping data. For instance, a previous study of combined shipping and air transport flows shows the persistent domination of world exchanges by Europe (Ducruet et al., 2011). Another important finding is the fragmentation of Europe in different areas and orientations, resulting in difficult 'readability' of a single European region. Most of the time, Europe is torn between North and South, with Northern ports having more widely spread connections and Southern ports remaining bound to the Mediterranean basin, although Southern ports do also have long-distance worldwide connections. The different analyses (i.e. subnetworks, foreland specialization) thus highlight the challenge of considering Europe as a single and integrated entity. Northern ports, which are characterized by a wider diversity and coverage of maritime connections, appear more integrated than Southern ports. Beyond sole physical and logistics factors, such a divide within Europe may reflect wider phenomena such as Europe's difficulty in realizing internal integration, as discussed in other chapters of the book. 
The study of foreland specialization points out the different orientations of major gateways towards specific post-colonial and resilient forelands as well as the spatial shrinkage of such trading ties during the period studied. Asian ports have captured a significant share of Europe's forelands, reinforced by increasing south-south flows outside the main poles. This study thus confirms the influence of major trade shifts on the distribution and specialization of Europe's internal and external port traffics. The maritime perspective offered is specific in the sense that it complements former analyses of other global flows, such as airlines and multinational firms, which suggest a maintained dominance of Europe and North America over the global economy (see Cattan, 2004; Bretagnolle et al., 2011). Although maritime flows mostly comprise raw materials and thus cannot be seen as the most strategic vector of globalization, they remain the backbone of international trade. Their current distribution thus expresses the potential of gateways and regions to organize the material pillars of the global economy.

\section{Acknowledgements}

The authors would like to thank Liliane Lizzi for cartographical support and Olaf Merk for complementing the data.

\section{References}

Bretagnolle A., Le Goix R., Vacchiani-Marcuzzo C. (2011) Métropoles et mondialisation, Paris: La Documentation Française.

Cattan N. (2004) Le monde au prisme des réseaux aériens, Flux, 58: 32-43.

Chaponnière, J. R. (2010) Le basculement de l'Afrique vers l'Asie : enjeux pour les ports africains, Afrique Contemporaine, 234(2): 25-40.

De Monie G., Rodrigue J.P. and Notteboom T.E. (2011) Economic cycles in maritime shipping and ports: The path to the crisis of 2008, in P.V. Hall, B. McCalla, C. Comtois and B. Slack (eds) Integrating Seaports and Trade Corridors. pp. 13-30. Surrey: Ashgate.

Ducruet C. (2008) Hub dependence in constrained economies: The case of North Korea, Maritime Policy and Management, 35(4): 377-394.

Ducruet C. (2012) The polarization of global container flows by interoceanic canals, Paper presented at the International Colloquium on Interoceanic Canals and World Seaborne Trade: Past, Present and Future, The Royal Academy for Overseas Sciences, Brussels, June 6-9.

Ducruet C., Ietri D. and Rozenblat C. (2011) Cities in worldwide air and sea flows: A multiple networks analysis, Cybergeo: European Journal of Geography, 528: http://cybergeo.revues.org/23603 
Ducruet, C., Notteboom, T.E. (2012) The worldwide maritime network of container shipping: Spatial structure and regional dynamics, 12(3): 395-423.

Ducruet C., Notteboom T.E. and De Langen P.W. (2009) Revisiting inter-port relationships under the New Economic Geography research framework, in Notteboom T.E., Ducruet C. and De Langen P.W. (Eds), Ports in Proximity: Competition and Coordination amaong Adjacent Seaports, pp. 11-27, Surrey: Ashgate.

European Union (2010) Travel time to major cities: A global map of accessibility, http://bioval.jrc.ec.europa.eu/products/gam/index.htm

Frémont A. (2007) Global maritime networks: The case of Maersk, Journal of Transport Geography, 15(6): 431442.

Guerrero D. (2012) French deep-sea hinterlands: Some empirical evidence of the spatial impact of containerisation, Paper presented at the International Association of Maritime Economists (IAME) Conference, Taipei, Taiwan, September 6-8.

Guy E. (2003) Shipping line networks and the integration of South America trades, Maritime Policy and Management, 30(3): 231-242.

Hall P.V., Hesse M. (2012) Cities, Regions, and Flows, Routledge: London and New York.

Joly, O. (1999) La structuration des réseaux de circulation maritime. Unpublished Phd dissertation in spatial planning, Le Havre University \& CIRTAI.

Lee S.W., Song D.W., Ducruet C. (2008) A tale of Asia's world ports: The spatial evolution in global hub port cities, Geoforum, 39(1): 372-385.

Lewis M.W. and Wigen K. (1999) A maritime response to the crisis in area studies, The Geographical Review 89(2): 161-168.

Marti G.E. and Krausse G.H. (1983) Trade route 11: Methods to assess port exchanges of maritime containerized cargo flows, Ocean Management, 8(4): 317-333.

Mohamed-Chérif F.Z., Ducruet C. (2011) Les ports et la façade maritime du Maghreb: Entre intégration régionale et mondiale, Mappemonde, 101: http://mappemonde.mgm.fr/num29/articles/art11103.html

Ng A.K.Y. and Ducruet C. (2012) Port geography bibliometrics (1950-2011): Community structure, background, and diffusion, Paper presented at the International Association of Maritime Economists (IAME) Conference, Clustering Logistics with Ports and Shipping Services in the time of Free Trade Era, Taipei, Taiwan, September $6-8$.

Notteboom T.E. (2010) Concentration and the formation of multi-port gateway regions in the European container port system: An update, Journal of Transport Geography, 18(4): 563-583. 
Puebla, J.G. (1987) Spatial structures of network flows: A graph theoretical approach. Transportation Research Part B, 21(6), 489-502.

Robinson R. (1970) The hinterland- foreland continuum: Concept and methodology, The Professional Geographer, 22(6): 307-310.

Robinson R. (2002) Ports as elements in value-driven chain systems: the new paradigm, Maritime Policy and Management, 29(3), 241-255.

Rodrigue, J.P., Comtois, C., Slack, B. (2009) The Geography of Transport Systems, Routledge, 2nd edition.

Shaw J., Sidaway J.D. (2010) Making links: On (re)engaging with transport and transport geography, Progress in Human Geography, 35(4): 502-520.

Ullmann, E.L. (1949) Mapping the world's ocean trade: A research proposal. The Professional Geographer, vol. $1, \mathrm{n}^{\circ} 2$, p. 19-22.

Vigarié A. (1979) Ports de commerce et vie littorale, Paris, Hachette.

Wang J.J., Ng A.K.Y. (2011) The geographical connectedness of Chinese seaports with foreland markets: A new trend? Tijdschrift voor Economische en Sociale Geografie, 102(2): 188-204.

Weigend G.G. (1952) Ports: Their hinterlands and 'forelands', Geographical Review, 42: 660-672. 
Figure 1: Largest shipping flows among world regions in 2004 and 2011

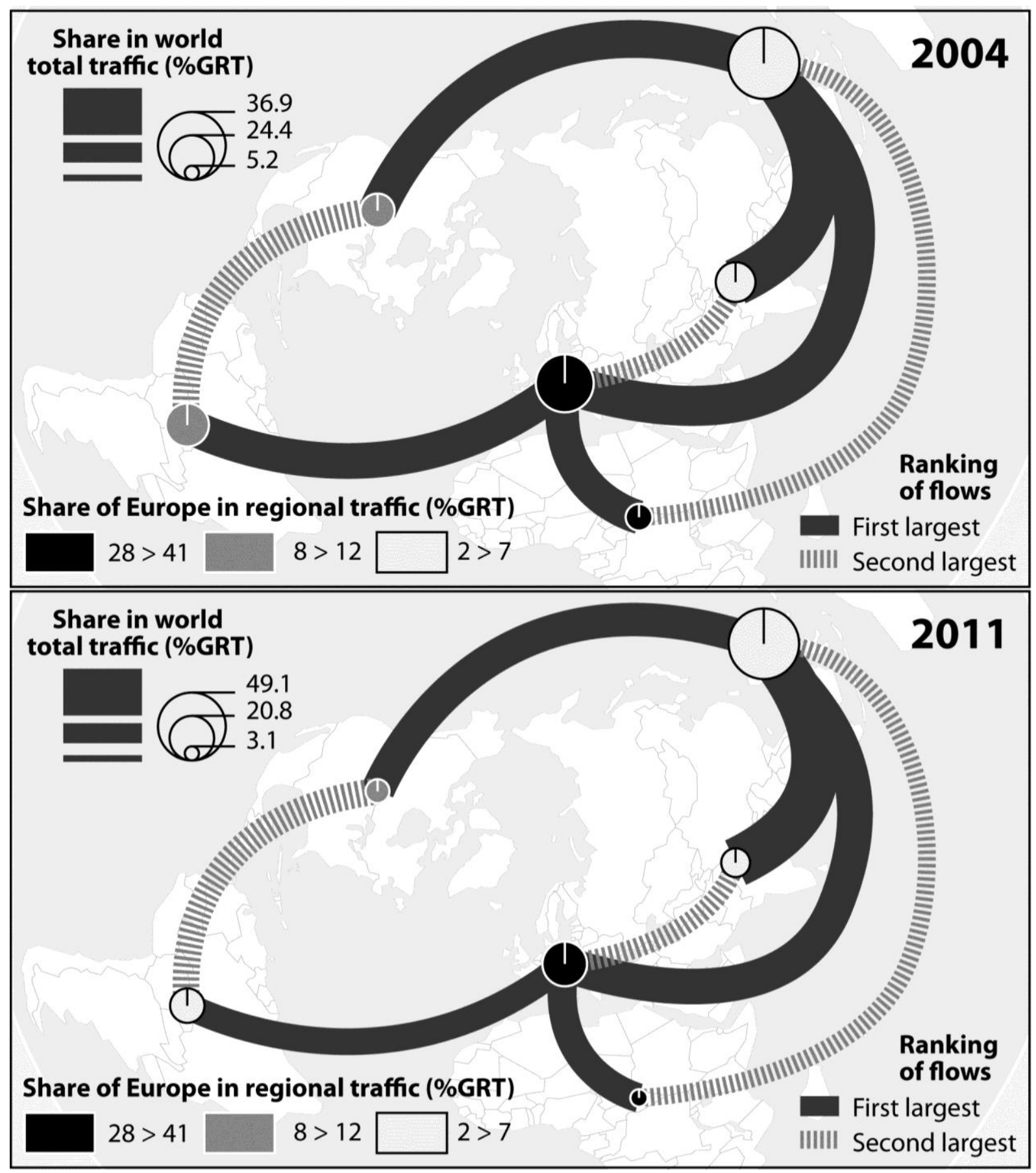

Source: own realization based on Lloyd's List data 
Figure 2: Largest shipping flows among world maritime ranges in 2004 and 2011
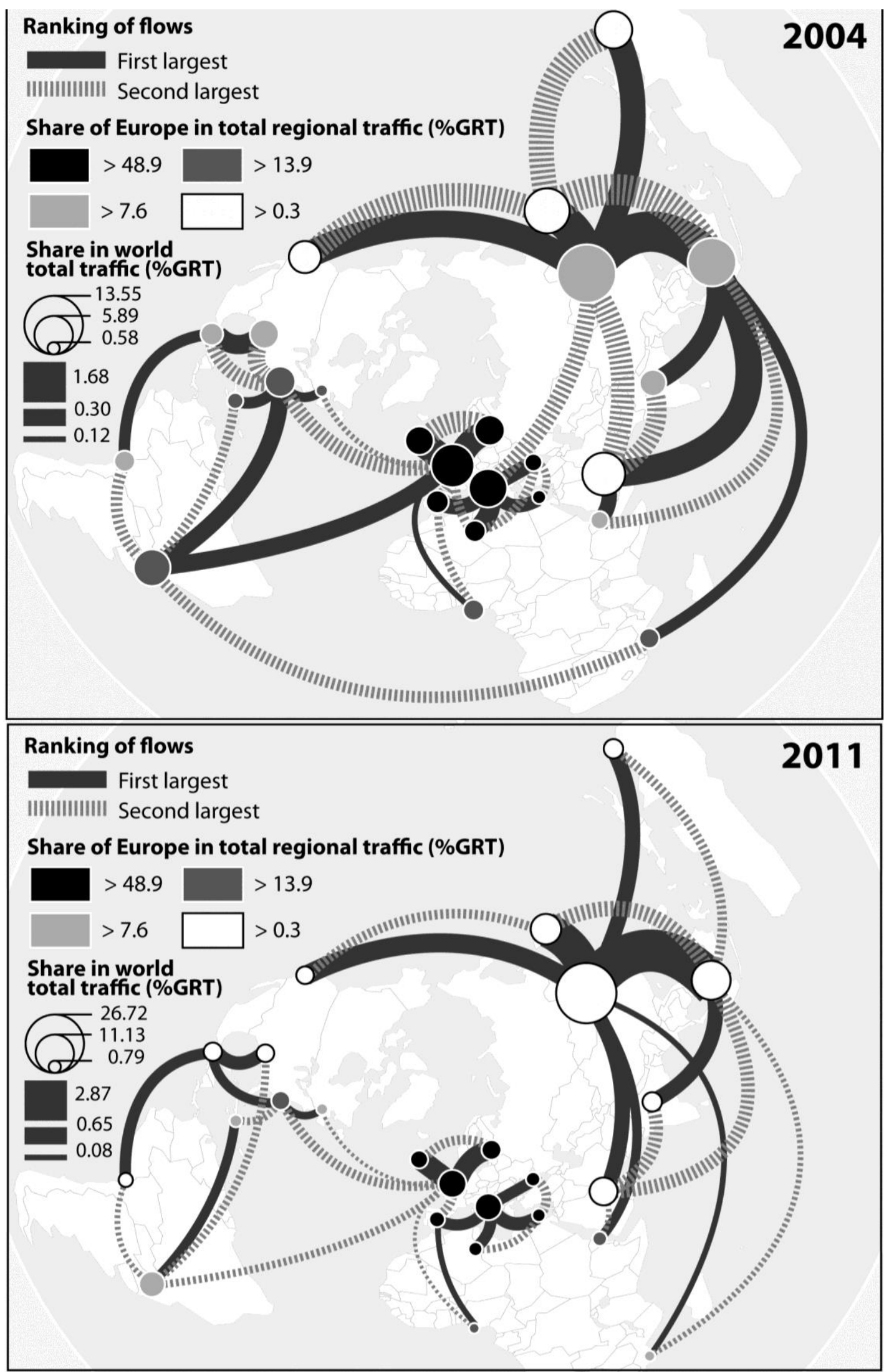

Source: own realization based on Lloyd's List data 
Figure 3: Weight and share of Europe at world ports in 2004 and 2011

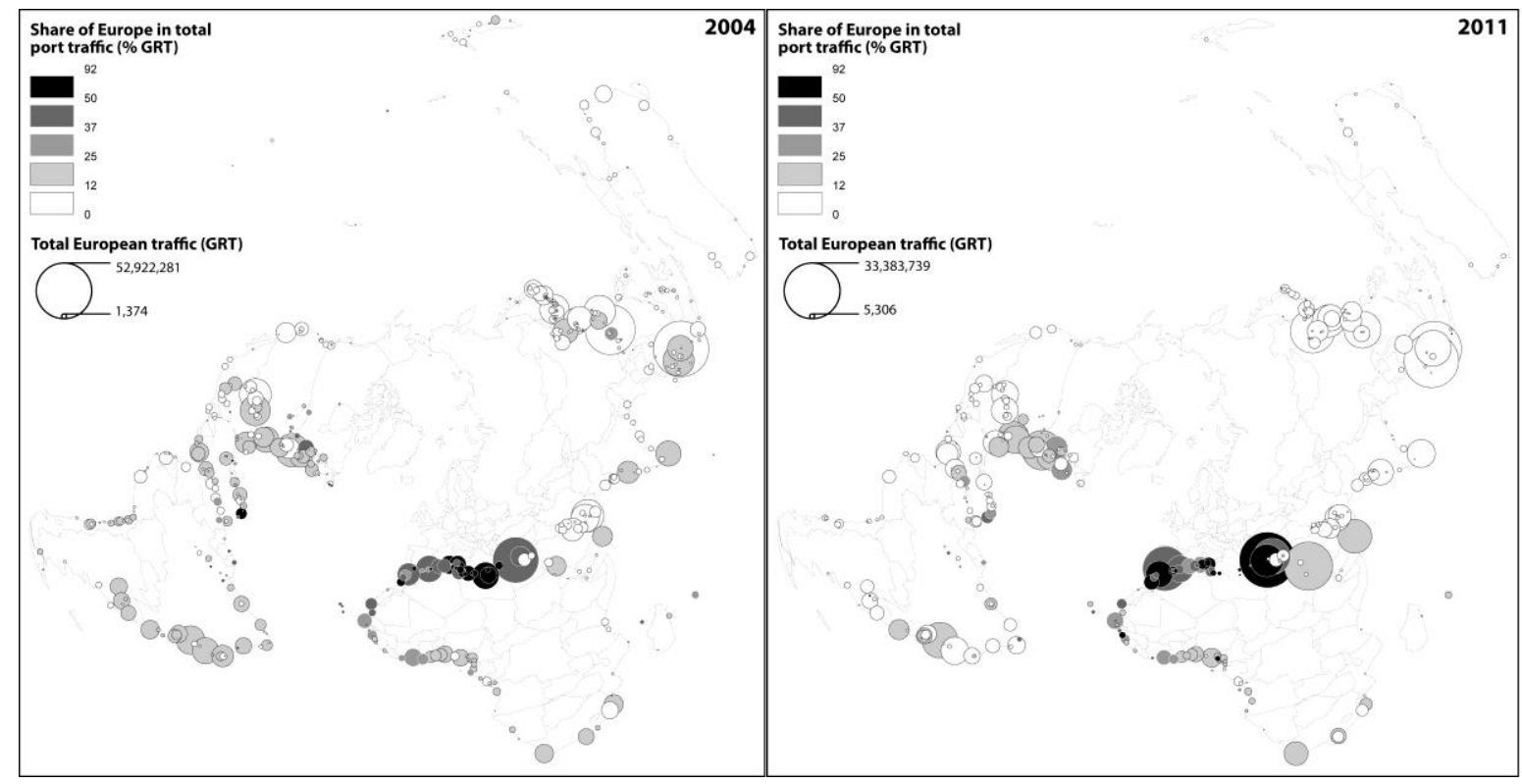

Source: own realization based on Lloyd's List data 
Figure 4: Single linkage analysis of global shipping flows in 2004 and 2011

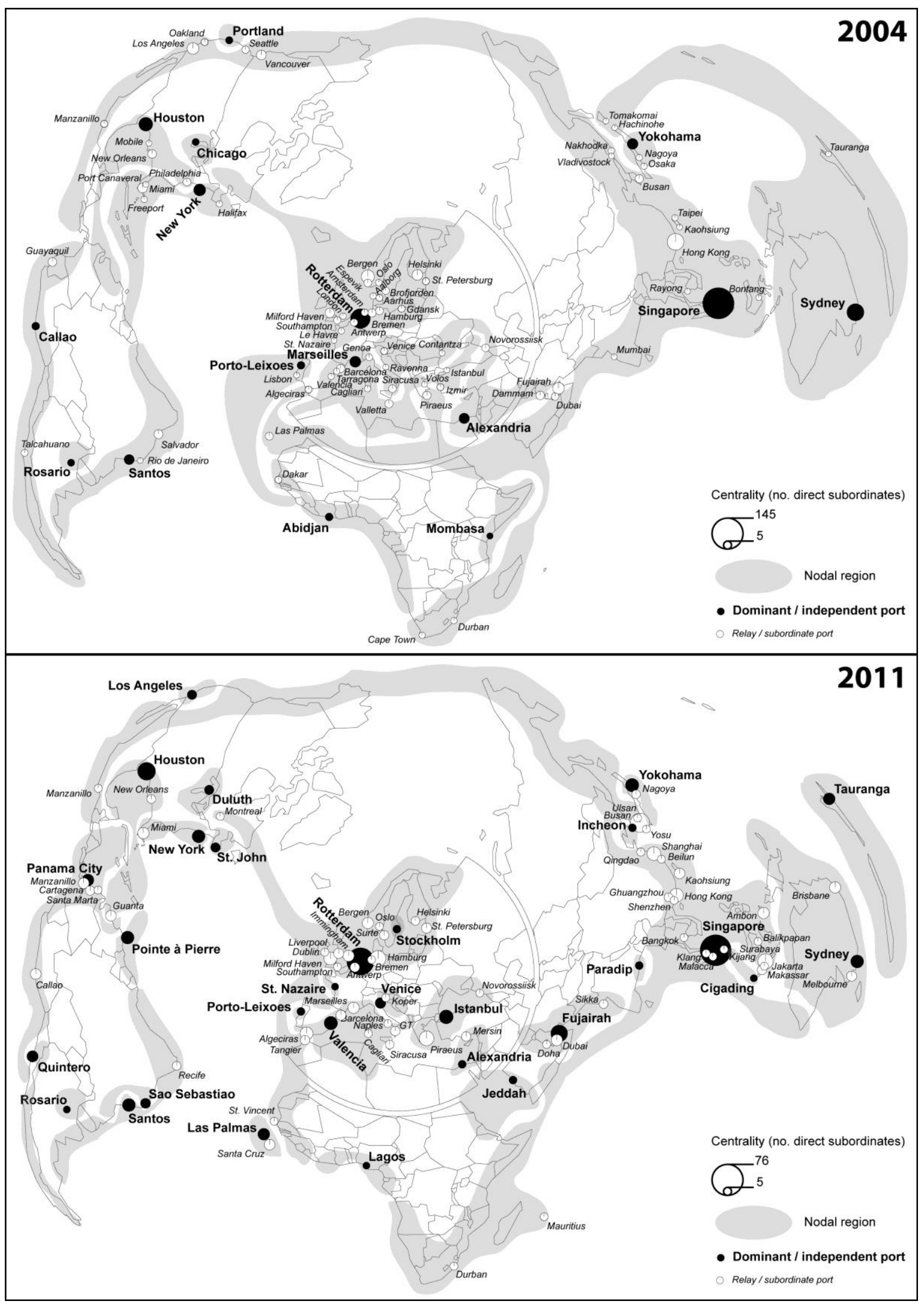

Source: own realization based on Lloyd's List data 
Figure 5: Foreland specialization clusters including main European ports in 2004 (left) and 2011 (right)

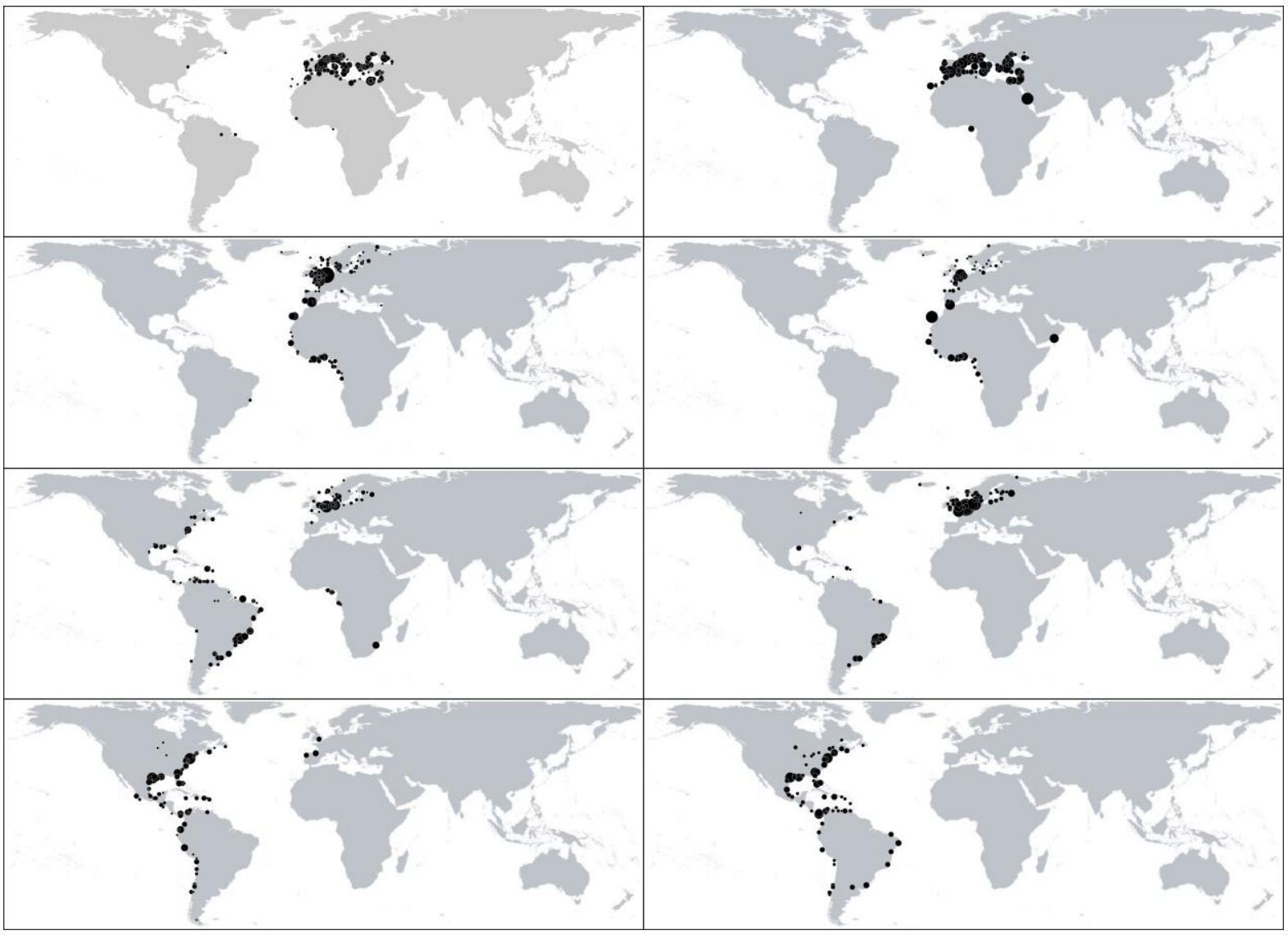

Source: own realization based on Lloyd's List data and StatistiXL 